\title{
Evaluation of Heavy Metals and Organic Compounds in Water Samples Collected from Various Sources from Republic of Moldova and Romania
}

\author{
CAROLINA UNTILA ${ }^{1,2}$, MIHAIL CARAMAN ${ }^{1}$, VALENTIN NEDEFF $23 *$, NARCIS BARSAN ${ }^{2 *}$, ION SANDU 4,5 , \\ ALEXANDRA DANA CHITIMUS'2, VASILE VALENTIN CRETU6, CLAUDIA TOMOZEI ${ }^{2}$, ANDREI VICTOR SANDU5,7 \\ ${ }^{1}$ Moldova State University, Faculty of Physics and Engineering, 60 Alexe Mateevici St., MD-2009 Chisinau, Republic of Moldova \\ ${ }^{2}$ Vasile Alecsandri University of Bacau, Department of Environmental Engineering and Mechanical Engineering, 156, Calea \\ Marasesti Str., 600115 Bacau, Romania \\ ${ }^{3}$ Gheorghe Ionescu Sisesti, Academy of Agricultural and Forestry Sciences Bucharest, 6 Marasti Blvd., 011464 Bucharest, \\ Romania \\ ${ }^{4}$ Alexandru Ioan Cuza University of lasi, Arheoinvest Interdisciplinary Platform, Scientific Investigation Laboratory, 11 Carol I \\ Blvd.,700506 lasi, Romania \\ ${ }^{5}$ Romanian Inventors Forum, 3 Sf. Petru Movila Str., Bloc L11, III/3, 700089 lasi, Romania \\ ${ }^{6}$ Gheorghe Asachi Technical University of Iasi, Hydrotechnical, Geodesy and Environment Faculty, 65 D. Mangeron Blvd.,700050 \\ Iasi, Romania \\ ${ }^{7}$ Gheorghe Asachi Technical University of lasi, Materials Science and Engineering Faculty, 53A D. Mangeron Blvd.,700050 lasi, \\ Romania
}

\begin{abstract}
This work presents the study and determination of composition of natural water samples collected from five different types of water sources from Republic of Moldova and Romania: river, lake, spring, fountain and rain. The purpose of this study was to establish whether some of the heavy metals and organic compounds with impact on population health are present in drinking water samples and if their presence falls within the set limits by national regulations. The analysis has been performed using VIS spectrophotometer with RFID technology and individual parameter express cuvette tests for water analysis which allowed ensuring high accuracy of the measurements. Thus, over limits high rates of $\mathrm{Pb}^{2+}$ and $\mathrm{Ni}^{2+}$ have been found in all samples. A high concentration of $\mathrm{F}^{-}$was determined from fountain water $-2.92 \mathrm{mg} / \mathrm{L}$ and of Fe from river $-0.701 \mathrm{mg} /$ $L$, which is twice than admissible values. The lowest concentration has been measured in the rainwater.
\end{abstract}

Keywords: water samples, heavy metals, organic compounds

Due to the fact that water is the root of the life and the best universal solvent, it is probably the only one substance in the world that might contain the "entire periodic system" in its composition. Water quality and treatment of wastewater represent a high interest among many researches within our Region [1-9]. At the same time, the determination of the presences of the microelements contained in the water samples have always represented a matter of interest and subject of study [10]. Moreover, it has been determined that high rates of water pollutants can affect severally human health or even the wealth of an entire population [11, 12]. Among the list of the pollutants of the drinking water, with the highest negative impact are heavy metals, as their presence in higher concentrations than admissible are toxic [12-19].

Heavy metals are considered metals with atomic weight higher than $5 \mathrm{~kg} / \mathrm{L}[13,14,19]$. They are among the most common pollutants that are found in fresh water $[13,14$, 17, 19]. Heavy metals like $\mathrm{Fe}^{2+}, \mathrm{Zn}^{2+}, \mathrm{Co}^{2+}, \mathrm{Ag}^{+}, \mathrm{Cu}^{2+}, \mathrm{Ni}^{2+}$ in trace quantities are essential nutrients involved in biochemical processes in human body [15], how ever high concentrations become toxic and align them to the harmful effect of $\mathrm{Pb}, \mathrm{Hg}$, As etc. Naturally, heavy metals that occur from earth's crust are introduced in aquatic systems by weathering of the rocks and soil, atmospheric deposition, metal corrosion or from volcanic eruptions [14, 16, 17, 19]. Nevertheless, due to high industrialization, unproper management of disposal, municipal wastewater, industrial waste, mining water [13, 14, 17-19] etc. these metals reach fresh water sources in very high concentration and by polluting, together with many other organic and inorganic compounds, make them unproper to be used and drunk.

After a thorough research, few studies were found on the matter of water quality in Republic of Moldova. However, most of them were made either on specific types of nonnatural sources or particular indicators [20-22]. Thus, the set aim of this study was to identify the presence of heavy metals and organic compounds with impact on population health, present in drinking water (natural sources water), to measure the concentration in water samples originating from various type of sources and to compare if their presence falls within the set limits by national regulations.

\section{Experimental part \\ Materials and methods}

The study area

In order to have a clearer picture on the presence of the pollution compounds, sampling has been made from different types of fresh water sources, namely:

-first sample was taken from the end section of the river Bic that passes by a lot of factories and the industrial sector of the Chisinau city. The river is considered to be one of the most polluted (Fig. 1) [23];

-second probe has been sampled from the 2 lake from the Valea Trandafirilor (Rose valley) park located S-E part region of the city Chisinau. The direct pollutants of the lake represent the waste from human activity and high rate of traffic that passes by (Fig. 2) [23];

-sample no. 3 was collected from a spring located in the $\mathrm{N}$ side valley of the village Cruzesti, near Chisinau (Fig. 3) [23];

\footnotetext{
* email: vnedeff@ub.ro; narcis.barsan@ub.ro
} 


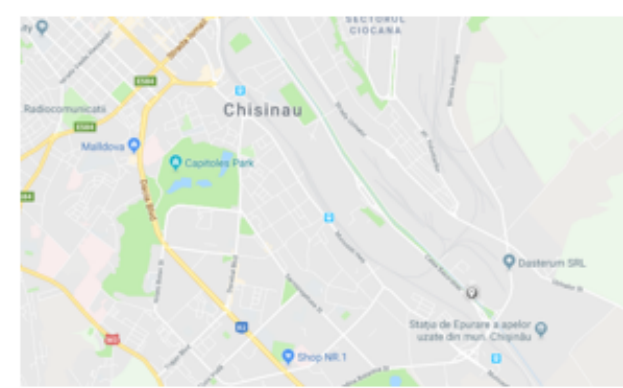

-4 sample was collected from a fountain in the village Cruzesti, near Chisinau, that was built in a residential neighborhood (Fig. 4) [23];

-probe no. 5 represent rainwater collected, in Chisinau as well, during the rain that was on 16 of April 2019. The specific of this sample is that there was no precipitation during more than one month (last was snow) and during that period;

-sample no 7, represent collected water from Slanic river, in the Bacau district, Romania, that is located in a mining area (Fig. 5) [23];

-eight sample was taken from Trotu' river, Targu Ocna, Romania, that passes thru a mining area as well (Fig. 6) [23];
Fig. 1. Sampling point from Bic River, Chisinau

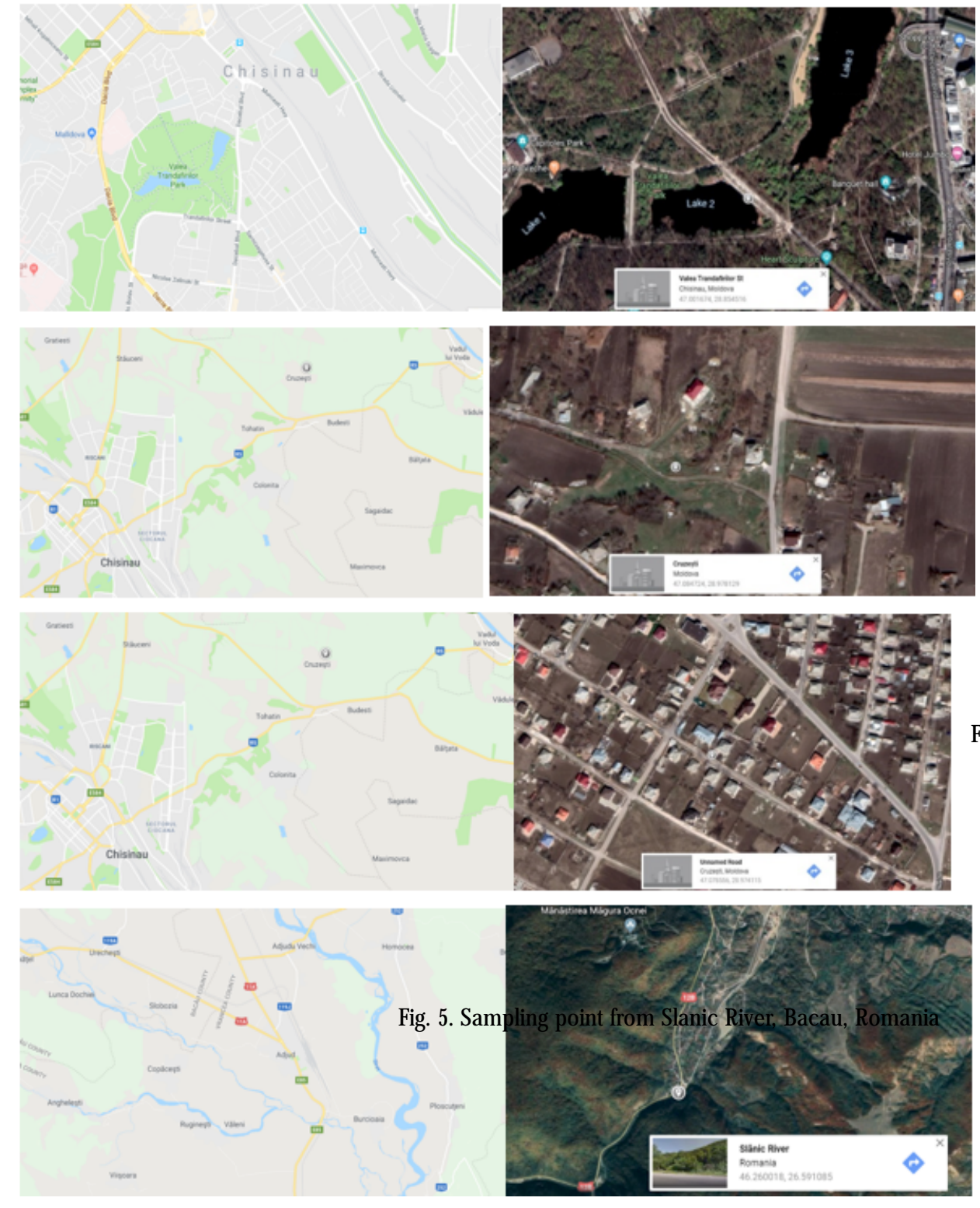

-last sample represent fountain water, collected from Targu Ocna, Romania.

In this way, we can have a further comparation on how different are or not the values of the dissolved components in the water samples, from different sources with specific pollutants. The sampling places were selected on aleatory bases, providing that the water comes from natural sources.

\section{Samples collection}

The test samples have been collected in PET (polyethylene) recipients in the minim amount of $1.5 \mathrm{~L}$, so there could be enough water samples for both qualitative and quantitative determinations. The probes have been collected in the middle of April 2019 from the locations

Fig. 2. Sampling point from Second lake from Valea Morilor, Chisinau

Fig. 3. Sampling point from spring, Cruzesti village near Chisinau

Fig. 4. Sampling point from fountaine, Cruzesti village near Chisinau

Fig. 5. Sampling point from Slanic River, Bacau, Romania 

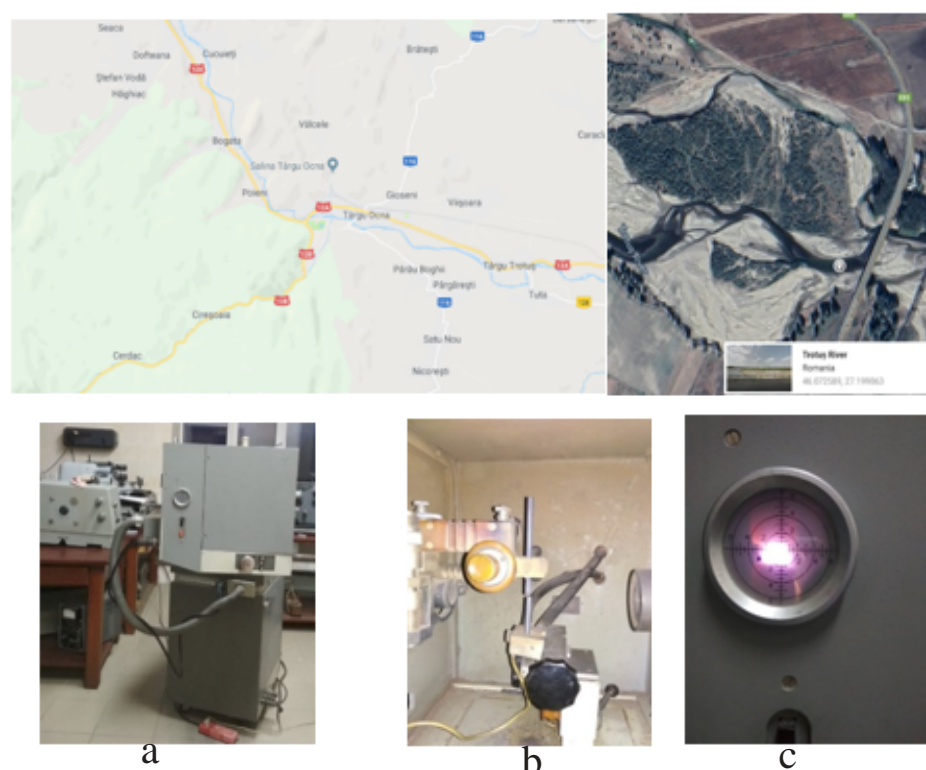

mentioned below, in accordance with ISO sampling Guide [24].

\section{Analysis performed}

The analysis has been performed in two stages. Firstly, there were provided qualitative determinations in order to identify which of the metals and other elements are present in the water samples.

The determinations were performed using the atomic emission spectrograph $\Delta \phi C-8$ (Fig. $7 a, b, c$ and d) that displays on photographic plaque the emission spectra obtained by burning electric arc the graphite electrode with sample.
Fig. 6. Sampling point from Trotus river, Bacau, Romania

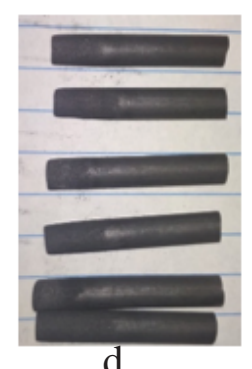

Fig. 7. Atomic emission spectrograph $\Delta \phi C$-8: a. outside burning chamber; b. electric arc between 2 graphite electrodes; c. inside burning chamber with 2 electrodes installed; $d$. burned graphite electrodes

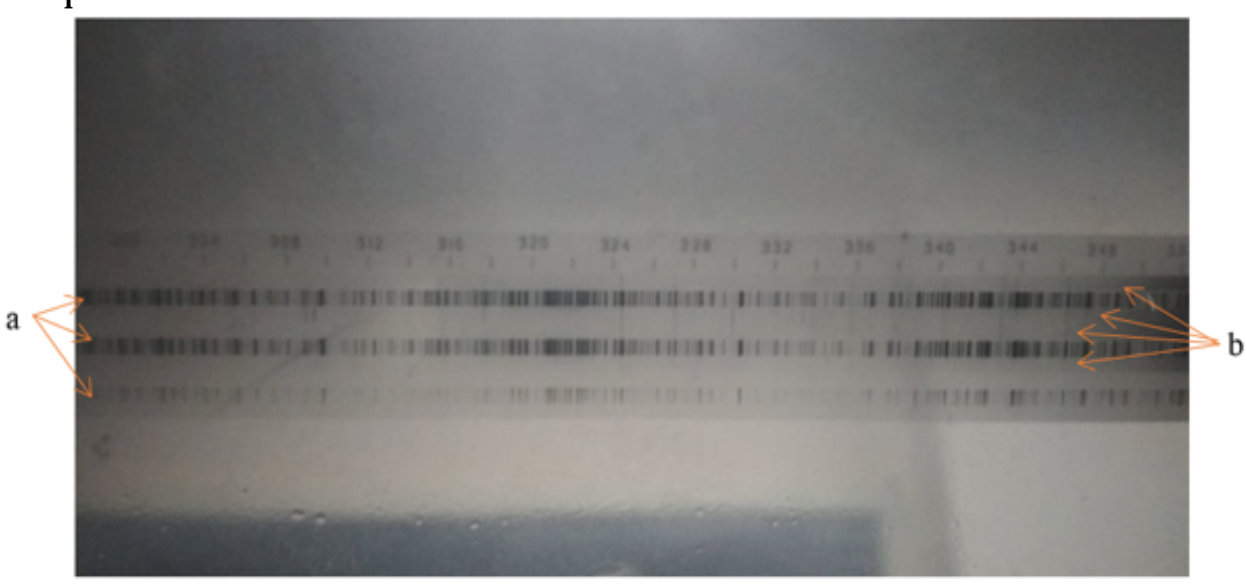

Fig. 8. Determined atomic emission spectra: a. Iron reference spectra; b. analyzed spectra

\begin{tabular}{|c|c|c|c|c|c|c|c|c|c|c|}
\hline $\begin{array}{l}\text { Comp. } \\
\text { tipes }\end{array}$ & CMA & Bic river & $\begin{array}{l}\text { Lake Valea } \\
\text { Trandafirilor }\end{array}$ & $\begin{array}{c}\text { Sprig } \\
\text { Cruzesti }\end{array}$ & $\begin{array}{l}\text { Fountain } \\
\text { Cruzesti }\end{array}$ & $\begin{array}{l}\text { Rain } \\
\text { water }\end{array}$ & $\begin{array}{c}\text { Slanic } \\
\text { river }\end{array}$ & $\begin{array}{c}\text { Trotus } \\
\text { river }\end{array}$ & Fountain & \multirow{9}{*}{$\begin{array}{c}\text { Table } 1 \\
\text { MEASURED } \\
\text { CONCENTRATION } \\
\text { VALUES (mg/L) OF } \\
\text { THE METALIC } \\
\text { CATIONS Ag }, \mathrm{Fe}^{2 / 3+} \\
\mathrm{Cu}^{2+}, \mathrm{Ni}^{2+}, \mathrm{Pb}^{2+}, \\
\mathrm{Mg}^{2+}, \mathrm{Al}^{3+} \text { and } \mathrm{Zn}^{2+}, \\
\text { IDENTIFIED IN } \\
\text { WATER SAMPLES }\end{array}$} \\
\hline $\begin{array}{c}\mathrm{Ag}^{*}, \lambda \\
460 \mathrm{~nm}\end{array}$ & - & 0.064 & 0.002 & 0.003 & 0.004 & 0.000 & 0.077 & 0.037 & 0.007 & \\
\hline $\begin{array}{l}\mathrm{Fe}^{2 / 3+}, \lambda \\
485 \mathrm{~nm}\end{array}$ & 0.3 & 0.248 & 0.112 & 0.087 & 0.114 & 0.292 & 0.701 & 0.459 & 0.104 & \\
\hline $\begin{array}{l}\mathrm{Cu}^{2+}, \lambda \\
478 \mathrm{~nm} \\
\end{array}$ & 1 & 0.217 & 0.161 & 0.140 & 0.120 & 0.134 & 0.439 & 0.329 & 0.227 & \\
\hline $\begin{array}{l}\mathrm{Ni}^{2+}, \lambda \\
466 \mathrm{~nm}\end{array}$ & 0.02 & 0.245 & 0.700 & 0.560 & 0.031 & 0.016 & 0.394 & - & - & \\
\hline $\begin{array}{l}\mathrm{Pb}^{2+}, \lambda \\
572 \mathbf{n m}\end{array}$ & 0.01 & 0.074 & 0.093 & 0.108 & 0.090 & 0.042 & 0.083 & 0.078 & 0.147 & \\
\hline $\begin{array}{l}\mathbf{M g}^{2+}, \lambda \\
570 \mathbf{n m}\end{array}$ & 50 & 46.30 & 41.30 & 49.00 & 20.80 & 4.13 & 7.44 & 8.72 & 40.40 & \\
\hline $\begin{array}{l}\mathrm{Al}^{3+}, \lambda \\
620 \mathrm{~nm}\end{array}$ & 0.2 & 0.003 & 0.000 & 0.000 & 0.000 & 0.000 & 0.023 & 0.011 & 0.000 & \\
\hline $\begin{array}{l}\mathrm{Zn}^{2+}, \lambda \\
490 \mathrm{~nm}\end{array}$ & 3 & 0.251 & 0.148 & 0.226 & 0.302 & 0.396 & 0.381 & 0.423 & 0.411 & \\
\hline
\end{tabular}


Afterwards the chemical elements present in water samples have been identified, quantitative measurements have been carried out in order to determine the concentration of the compounds.

The concentration of the compounds in water samples have been measured using the DR 3900 Hach Spectrophotometer and cuvette test kits. The instrument and test kits are manufactured by Hach Lange Company from US. Cuvette test kits are designed for a single parameter determination according to the established international and/or Hach own developed methods, which offer high precision and express sample preparation. Each kit is accompanied by method data sheet and sample preparation instructions.

The transmittance measurements of the $\mathrm{F}^{-}, \mathrm{SO}^{2-}, \mathrm{Mg}^{2+}$ and $\mathrm{Al}^{3+}$, and heavy metals $\left(\mathrm{Ag}^{+}, \mathrm{Fe}^{2 / 3+}, \mathrm{Cu}^{2+}, \mathrm{Zn}^{2+}, \mathrm{Ni}^{2+}\right.$ and $\mathrm{Pb}^{2+}$ ) from the water samples have been carried out in the Laboratory Analysis of Water from the University Vasile Alecsandri from Bacau, Romania.

\section{Results and discussions}

The results of the performed measurements were compared with the CMAs, that have been selected in accordance with the Sanitary Standards for Drinking Water Quality, adopted by the Government Decision on the

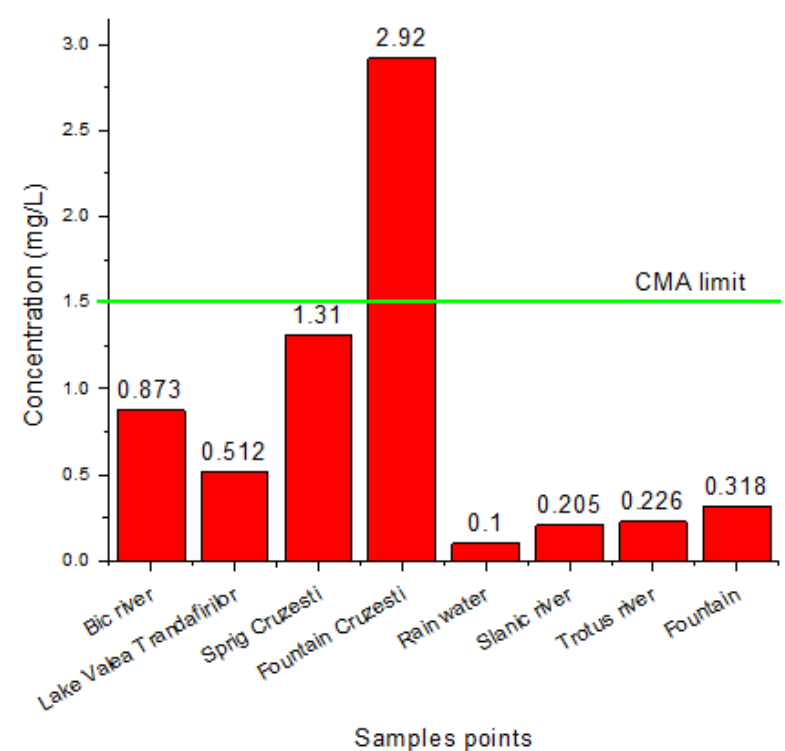

Fig. 9. Concentration variation for F- compound in the analyzed

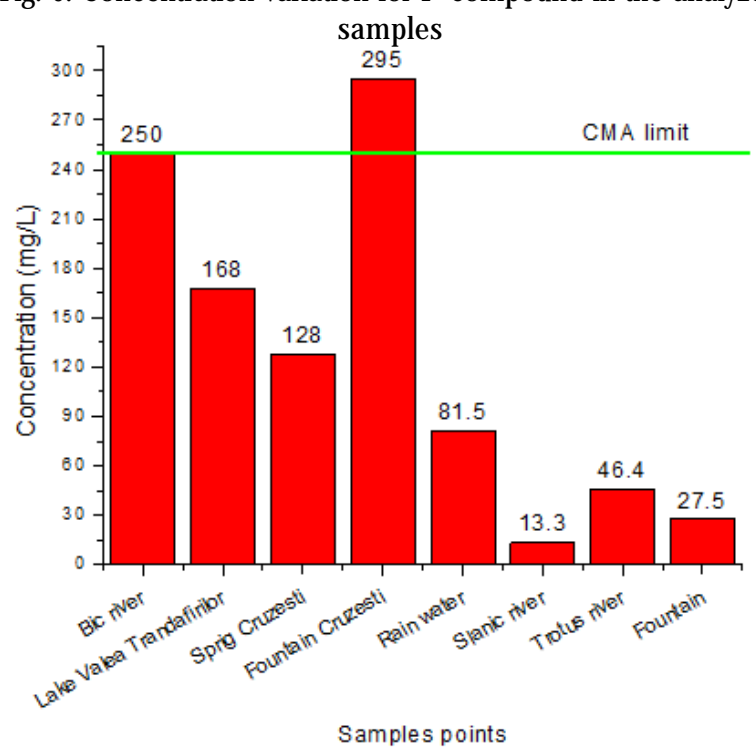

Fig. 10. Concentration variation for $\mathrm{SO}_{4}{ }^{2-}$-compound in the analyzed samples

REV.CHIM.(Bucharest) 70 No. $10 \bullet 2019$

http://www.revistadechimie.ro
Establishment of the Automated Information System State Register of Natural Mineral Water, Drinks and Bottled Soft Drinks 934 of 15.08.2007. In: No. 131-135 of 24.08.2007, [23] and presented in the table 1 for the $\mathrm{Ag}^{+}, \mathrm{Fe}^{2 / 3+}, \mathrm{Cu}^{2+}$, $\mathrm{Ni}^{2+}, \mathrm{Pb}^{2+}, \mathrm{Mg}^{2+}, \mathrm{Al}^{3+}$ and $\mathrm{Zn}^{2+}$, Figure 9 for $\mathrm{F}$-and Figure 10 for $\mathrm{SO}^{2-}$.

Analyzing the data from the table 1 and figures 9 and 10 can be observed that the most polluted samples from Republic of Moldova are the samples from Bic River and Sprig from Cruzesti. The Bic river sample shows high values specific for the pollutants present in abundance along the river on the territory of Chisinau. The river passes by several factories: closed leather, tobacco processing and pharmacology factories, is crossed in several points by high traffic streets and flows thru the industrial zone along to a high traffic street. As result, high concentrations of $\mathrm{Pb}^{2+}$, $\mathrm{Ni}^{2+}, \mathrm{Mg}^{2+}, \mathrm{Fe}^{2 / 3+}$ and $\mathrm{F}^{-}$were registered.

The other, most polluted sample is the spring water from Cruzesti. The spring is located at the foot of the village. It registers considerable high values of $\mathrm{Ni}^{2+}$ and $\mathrm{Pb}^{2+}$, and $\mathrm{SO}_{4}^{2-}$, which makes water dangerous.

The measured concertation values can be related to the studies of Ruslan Melian, et. al related to Groundwater quality and rural drinking-water supplies in the Republic of Moldova [25, 26]. However, the measurements have been made two decades ago and the samples were particularly from groundwater sources. Also, the samples from Romania, register high values of $\mathrm{Fe}^{2 / 3+}, \mathrm{Ni}^{2+}$ and $\mathrm{Pb}^{2+}$ [27].

The results of the measurements show us that the water quality of none of the samples correspond to the CMAs, which means that the water from the natural sources cannot be used as a drinking water without previously being treated.

\section{Conclusions}

As a result of the measurements made, we have established that in the samples of drinking water there are large quantities of heavy metals, even above the permissible limits, which represents an increased danger for the health of the animals and people who consume water from these sources.

Particularly alarming is the high content of Fluorine from wells in the Republic of Moldova, this element having negative effects on human health, being classified as neurotoxin and was included in the same category as arsenic, lead and mercury.

Furthermore, we consider that the measurements should be repeated, respecting the same methodology, by collecting and comparing the same types of samples in order to establish an up to date list of some of the heavy metal's concentrations from natural water sources.

\section{References}

1.BARSAN, N., J OITA, I., STANILA, M., RADU, C., DASCALU, M., Modelling wastewater treatment process in a small plant using a Sequencing Batch Reactor (SBR), Environmental Engineering and Management J ournal, 13, no. 7, 2014, p. 1561-1566.

2.BARSAN, N., NEDEFF, V., TEMEA, A., MOSNEGUTU, E., CHITIMUS, A.D., TOMOZEI, C., A perspective for poor wastewater infrastructure regions: a small-scale Sequencing Batch Reactor treatment system, Chemistry journal of Moldova, 12, no. 1, 2017. p. 61-66.

3.COCHIORCA, A., NEDEFF, V., BARSAN, N., MOSNEGUTU, E.F, PANAINTE-LEHADUS, M., Aspects related to water quality assessment in a mining activityarea. Case study, mining area Targu Ogna, Romania. International Multidisciplinary Scientific GeoConference: SGEM: Surveying Geology \& mining Ecology Management, 18, 2018, p. 87-94. 4.FABIAN, F., NEDEFF, V., BIRSAN, N., MOSNEGUTU, E., Energy and Chemicals Consumption Evaluation in Water Treatment Plant $A$ 
comparative study between Bacau and Turin, Rev.Chim. (Bucharest), 70, no. 3, 2019, p. 881-886.

5.IRIMIA, O., TOMOZEI, C., PANAINTE, M., MOSNEGUTU, E.F., BARSAN, N., Efficiency of filters with different filtering materials: comparative study in water treatment, Environmental Engineering and Management Journal, 12, no. 1, 2013, p. 35-39.

6.TATARU, L., NEDEFF, V., BARSAN, N., MOSNEGUTU, E., PANAINTELEHADUS, M., SANDU, I., CHITIMUS, D., Studies of Humic Acid Removal from Aqueous Systems by Using Polymeric Membrane Ultrafiltration Process, Mat. Plast., 55, no. 4, 2018, p. 660-685.

7.TATARU, L., NEDEFF, V., BARSAN, N., SANDU, A.V., MOSNEGUTU, E., PANAINTE-LEHADUS, M., SANDU, I., Applications of Polymeric Membranes Ultrafiltration Process on the Retention of Bentonite Suspension, Mat. Plast., 56, no. 1, 2019, p. 97-102.

8.MISAILA, L., NEDEFF, F.M., BARSAN, N., SANDU, I.G., GROSU, L., PATRICIU, O.I., GAVRILA, L., FINARU, A.L., WATERSHED - android application for the mineral waters, classification, Rev.Chim. (Bucharest), 70, no. 6, 2019, p. 2212-2217.

9.EBLIN, S.G., KONAN, K.S., MANGOUA, O.M.J ., NEDEFF, V., SANDU, A.V., BARSAN, N., SANDU, I., Nitrate Pollution of Groundwater Based on GIS in the City of Daloa, West-central Cote d'Ivoire, Rev.Chim. (Bucharest), 70, no. 7, 2019, p. 2579-2583.

10.KIM, J.S., JAIN, S., LEE, J.H., CHEN, H., PARK, S.Y., Quantitative vulnerability assessment of water quality to extreme drought in a changing climate, Ecological Indicators, 103, 2019, p. 688-697.

11.MANESCU, S., Hygiene dissertation, (in Romanian), vol. 1, Medicala Publishing House, Bucuresti, 1984.

12.BAHNAREL, I., Strategies of the 5th European Inter-ministerial Conference on health and environment issues, (in Romanian), Proceeding of the Conference Risk factors for the environment and health, 2010, Chisinau, p. 12-14.

13.ROSENBERG, E., Heavy Metals in Water: Presence, Removal and Safety, Johnson Matthey Technology Review, 2015, 59, no. 4, p. 293297.

14.TCHOUNWOU, P.B., YEDJ OU, C.G., PATLOLLA, A.K., SUTTON, D.) ., Heavy metal toxicity and the environment, in molecular, clinical and environmental toxicology, 2012, Springer, p. 133-164.

15.*** World Health Organization, Trace elements in human nutrition and health, 1996, https://www.who.int/nutrition/publications/ micronutrients/9241561734/en/ (24.06.2019).
16.NOVAKOVA, S., NIKOLCHEV, G., MAUTNER, G., ANGELIEVA, R., DINOEVA, S., Effect of several microelements contained in drinking water on the development of atherosclerosis, Problemi na khigienata, 8, 1983, p. 121-131.

17.J ARUP, L., Hazards of heavy metal contamination, British medical bulletin, 68, no. 1, 2003, p. 167-182.

18.OSTROFET, G., CIOBANU, E., GROZA, L., COSTIC, N., EREMCIU, T., Study of chemical composition of mine water in well in rural areas of the Republic of Moldova, Analele Stiintifice ale USMF N. Testemitanu, 12, no. 2, 2011, p. 102-107.

19.BRADL, H., Heavy metals in the environment: origin, interaction and remediation, vol. 6. Elsevier, 2005.

20.BUMBU, I., GUTU, D., Heavy metals as pollutants of aquatic ecosystems, (in Romanian) 2012, https://utm.md/meridian/2012/ MI 3 2012/5 Art Bumbu.pdf.

21.MOOGOREAN, M., BERNIC, V., CIOBANU, E., CROITORU, C., CEBANU, S., Comparative hygienic assessment of the water quality from different sources of the Republic of Moldova: descriptive study, Revista de Stiinte ale Sanatatii din Moldova, 3, no.13, 2017, p. 59-65.

22.SANDU, M., TARITA, A., LOZAN, R., TURCAN, S., The geochemical index and the degree of underground sediments pollution with heavy metals in the Republic of Moldova, Studia Universitatis Moldaviae Stiine Reale si ale Naturii, 111, no. 1, 2018, p. 179- 187.

23.*** https://www.google.ro/maps.

24.*** ISO 5667-1:2006 Water quality -Sampling -Part 1: Guidance on the design of sampling programmers and sampling techniques, https:/ /ww w.iso.org/standard/36693.html

25.*** Sanitary Standards for Drinking Water Quality, adopted by the Government Decision on the Establishment of the Automated Information System State Register of Natural Mineral Water, Drinks and Bottled Soft Drinks G.o.R.o. Moldova, Editor. 15.08.2007, Official Monitor of the Republic of Moldova.

26.MELIAN, R., MYRLIAN, N., GOURIEV, A., MORARU, C., RADSTAKE,

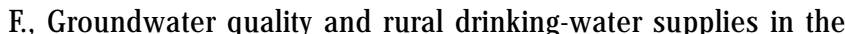
Republic of Moldova, Hydrogeology J ournal, 7, no. 2, 1999, p. 188-196. 27.COCHIORCA, A., NEDEFF, V., BARSAN, N., PANAINTE-LEHADUS, M., MOSNEGUTU, E.F., Aspects related to water quality assessment in a mining activity area. Case study, mining area Tg. Ogna, Romania, Proceeding of the International Multidisciplinary Scientific Geo Conference Surveying Geology and Mining Ecology Management, SGEM, 18, (3.1), 2018, p. 87-94.

Manuscript received: 14.09 .2019 